\title{
Pemodelan Faktor-faktor yang Mempengaruhi Tingkat Partisipasi Angkatan Kerja Perempuan di Jawa Barat Menggunakan Regresi Nonparametrik Spline Truncated
}

\author{
${ }^{1}$ Nurul Izzah, ${ }^{2}$ I Nyoman Budiantara \\ Departemen Statistika, Fakultas Sains dan Analitika Data, \\ Institut Teknologi Sepuluh Nopember (ITS) \\ J1. Arief Rahman Hakim, Surabaya 60111 Indonesia \\ e-mail:1nurulizzah131.ni@gmail.com, ${ }^{2}$ _nyoman_b@statistika.its.ac.id
}

\begin{abstract}
Abstrak-Tingkat Partisipasi Angkatan Kerja (TPAK) merupakan ukuran proporsi penduduk usia kerja suatu daerah yang bergerak aktif di pasar tenaga kerja dan menjadi faktor penting dalam menggerakan pembangunan. Proses pembangu-nan di suatu negara tidak bisa terlepas dari peran perempuan, khususnya dalam kegiatan ekonomi. Di Jawa Barat, nilai TPAK perempuan sebesar 42,37\% tahun 2018. Angka tersebut termasuk rendah jika dibandingkan dengan nilai TPAK perem-puan di daerah lain. Penyebab rendahnya TPAK perempuan dipengaruhi beberapa faktor, untuk mengetahui faktor yang mempengaruhinya dilakukan penelitian menggunakan Regresi Nonparametrik Spline Truncated. Karena pola hubungan yang ditunjukan antara persentase TPAK perempuan dengan faktor-faktor yang diduga mempengaruhinya tidak mengikuti pola tertentu. Berdasarkan nilai GCV yang paling minimum, model terbaik adalah menggunakan kombinasi titik knot $(1,2,3,1)$. Hasil pengujian signifikansi parameter menunjukkan bahwa terdapat empat variabel yang berpengaruh signifikan terhadap persentase TPAK perempuan di Jawa Barat yaitu persentase perempuan dengan pendidikan tertinggi yang dita-matkan minimal SLTA, persentase perempuan berstatus menikah, UMK, dan PDRB per kapita. Serta hasil pengujian asumsi residual menunjukkan semua asumsi terpenuhi dengan nilai koefisien determinasi dari model sebesar $94,59 \%$.
\end{abstract}

Kata Kunci-- GCV, Jawa Barat, Regresi Nonparametrik Spline Truncated, TPAK Perempuan, Titik Knot.

\section{PENDAHULUAN}

K etenagakerjaan merupakan salah satu isu penting di dalam perekonomian. Hal ini disebabkan karena tenaga kerja adalah salah satu faktor utama yang dapat menunjang keberhasilan ekonomi suatu negara. Pembangunan ekonomi di suatu negara tidak bisa lepas dari keikutsertaan seluruh lapisan masyarakat, termasuk peranan perempuan. Keterlibatan perempuan yang mayoritas dalam pekerjaan domestik dapat dilihat melalui Tingkat Partisipasi Angkatan Kerja (TPAK) perempuan. International Labour Organiza-tion (ILO) merumuskan bahwa TPAK adalah ukuran proporsi penduduk usia kerja suatu negara yang bergerak aktif di pasar tenaga kerja, baik dengan bekerja atau mencari pekerjaan terhadap populasi penduduk usia kerja. TPAK menghitung jumlah penduduk dalam angkatan kerja sebagai persentase dari penduduk usia kerja [1].
Perkembangan pasar tenaga kerja di Indonesia mengalami peningkatan sepanjang tahun 2017 hingga 2018. Hal ini terbukti dengan meningkatnya jumlah pekerja dan menurunnya angka pengangguran yang semula 5,5 persen menjadi 5,34 persen di tahun 2018. Namun, dari semua indikator pasar tenaga kerja yang ada, partisipasi perempuan masih tertinggal. Jawa Barat menduduki peringkat pertama dengan jumlah penduduk terbanyak di Indonesia, yaitu diperkirakan sebanyak 48.683.860 jiwa pada tahun 2018 . Dimana, perbandingan jumlah penduduk perempuan dan penduduk laki-laki tidak jauh berbeda. Berdasarkan fakta tersebut, keterlibatan perempuan dalam aktivitas perekonomian masih sangat kurang. Hal ini dapat dilihat dari Provinsi Jawa Barat yang memiliki nilai TPAK perempuan yang tergolong rendah pada tahun 2018 yaitu sebesar 42,37 persen, sedangkan TPAK laki-laki sebesar 83,09 persen [2].

Penelitian ini menggunakan faktor-faktor yang diduga mempengaruhi TPAK perempuan diantaranya persentase perempuan dengan pendidikan tertinggi yang ditamatkan minimal SLTA, persentase perempuan usia produktif, persentase perempuan berstatus menikah, UMK, dan PDRB. Metode yang digunakan dalam memodelkan faktor-faktor yang mempengaruhi TPAK perempuan di Jawa Barat menggunakan regresi nonparametrik spline truncated. Hal ini didasarkan karena tidak terbentuknya pola tertentu pada kurva regresi antara variabel respon dengan variabel prediktor. Selanjutnya, apabila kurva regresi tersebut dipotong-potong pada titik tertentu akan terlihat bentuk pola pada masingmasing daerah yang terbentuk, sehingga memerlukan metode yang memiliki sifat fleksibilitas dalam menangani perilaku data.

\section{TINJAUAN PUSTAKA}

\section{A. Regresi Nonparametrik Spline Truncated}

Regresi nonparametrik spline truncated merupakan metode yang paling banyak digunakan pada regresi nonparametrik. Bentuk kurva spline terpotong-potong sehingga mampu mengatasi perubahan pola data pada sub interval tertentu. Pada metode regresi nonparametrik spline truncated digunakan bantuan titik-titik knot yaitu pola perubahan perilaku dari suatu fungsi pada selang yang berbeda [4]. 


$$
f\left(x_{i}\right)=\sum_{j=0}^{m} \beta_{j} x_{i}^{j}+\sum_{k=1}^{r} \beta_{m+k}\left(x_{i}-K_{k}\right)_{+}^{m} .
$$

sehingga diperoleh persamaan model regresi nonparametrik spline truncated sebagai berikut.

$$
y_{i}=\sum_{j=0}^{m} \beta_{j} x_{i}^{j}+\sum_{k=1}^{r} \beta_{m+k}\left(x_{i}-K_{k}\right)_{+}^{m}+\varepsilon_{i}, \quad i=1,2, \cdots, n .
$$

Fungsi truncated $\left(x_{i}-K_{k}\right)_{+}^{m}$ menghasilkan persamaan berikut.

$$
\left(x_{i}-K_{k}\right)_{+}^{m}=\left\{\begin{array}{cc}
\left(x_{i}-K_{k}\right)^{m} & , x_{i} \geq K_{k} \\
0 & , x_{i}<K_{k}
\end{array}\right.
$$

dimana,

$\beta_{j} \quad$ : parameter model polinomial, $j=1,2, \ldots, m$

$X_{i} \quad$ : variabel prediktor $i=1,2, \ldots, n$

$\beta_{m+k}$ : parameter pada komponen truncated $k=1,2, \ldots, r$

$r \quad$ : banyaknya knot

$K_{k} \quad$ : titik knot yang menunjukkan perubahan pola data

\section{B. Pemilihan Titik Knot Optimum}

Model regresi spline terbaik merupakan model yang memiliki titik knot optimal. Titik knot merupakan titik yang terdapat pada perubahan pola perilaku fungsi. Salah satu metode yang biasa digunakan untuk memilih titik knot optimal adalah metode Generalized Cross Validation (GCV). Titik-titik knot optimal diperoleh dari nilai GCV paling minimum [5].

$$
\operatorname{GCV}\left(K_{1}, K_{2}, \ldots, K_{r}\right)=\frac{\operatorname{MSE}\left(K_{1}, K_{2}, \ldots, K_{r}\right)}{\left(n^{-1} \operatorname{tr}\left[\mathbf{I}-A\left(K_{1}, K_{2}, \ldots, K_{k}\right)\right]\right)^{2}}
$$

dengan I adalah matriks identitas, $n$ merupakan banyak pengamatan, dimana $A\left(K_{1}, K_{2}, \ldots, K_{k}\right)=\mathbf{X}\left(\mathbf{X}^{\prime} \mathbf{X}\right)^{-1} \mathbf{X}^{\prime}$, dan $\operatorname{MSE}\left(K_{1}, K_{2}, \ldots, K_{k}\right)=\mathrm{n}^{-1} \sum_{i=1}^{n}\left(y_{i}-\hat{y}_{i}\right)^{2}$

C. Pengujian Parameter Model

Pengujian parameter model dilakukan untuk menentukan variabel prediktor yang berpengaruh terhadap variabel respon. Terdapat dua tahap pengujian parameter yaitu pengujian secara serentak dan secara parsial.

a. Uji Serentak

Hipotesis :

$\mathrm{H}_{0}: \beta_{1}=\beta_{2}=\cdots=\beta_{m+r}=0$

$\mathrm{H}_{1}$ : Minimal ada satu $\beta_{j} \neq 0, j=1,2, \ldots, m+r$

Statistik uji :

$$
F_{\text {hitung }}=\frac{\sum_{i=1}^{n}\left(\hat{y}_{i}-\bar{y}\right)^{2} /(m+r)}{\sum_{i=1}^{n}\left(y_{i}-\hat{y}_{i}\right)^{2} /(n-(m+r)-1)}
$$

Dimana $m$ adalah jumlah variabel prediktor kecuali $\beta_{0}$ dan $r$ adalah jumlah titik knot. Daerah penolakan untuk uji serentak adalaha jika $F_{\text {hitung }}>F_{\alpha,(m+r, m-p-r-1)}$ atau $p$-value $<\alpha$.

b. Uji Parsial

Hipotesis :

$\mathrm{H}_{0}: \beta_{j}=0$

$\mathrm{H}_{1}: \beta_{j} \neq 0, j=1,2, \ldots, m+r$

Statistik uji :

$$
t_{\text {hitung }}=\frac{\hat{\beta}_{j}}{S E\left(\hat{\beta}_{j}\right)}
$$

Daerah penolakan $\mathrm{H}_{0}$ adalah apabila $t_{\text {hitung }}>t_{(\alpha / 2, n-(m+r)-1)}$ atau $p$-value $<\alpha$.

\section{Koefisien Determinasi}

Koefisien determinasi adalah kuantitas yang dapat menjelaskan sumbangan variabel prediktor terhadap variabel respon. Semakin tinggi nilai $R^{2}$ yang dihasilkan suatu model, maka semakin baik pula variabel-variabel prediktor dalam model tersebut dalam menjelaskan variabilitas variabel respon [6]. Berikut ini adalah rumus untuk mendapatkan nilai $R^{2}$.

$$
R^{2}=\frac{S S_{\text {Regresi }}}{S S_{\text {Total }}}=\frac{\sum_{i=1}^{n}\left(\hat{y}_{i}-\bar{y}\right)^{2}}{\sum_{i=1}^{n}\left(y_{i}-\bar{y}\right)^{2}}
$$

Pemilihan model juga akan menunjukkan banyaknya parameter yang digunakan dalam model tersebut. Seperti yang dijelaskan dalam prinsip parsimoni, suatu model regresi yang baik adalah model regresi dengan banyak parameter yang sesedikit mungkin tetapi mempunyai $R^{2}$ yang cukup tinggi.

\section{E. Pengujian Asumsi Residual}

Pengujian asumsi residual dilakukan apabila model terbaik dari regresi spline telah didapatkan. Terdapat tiga asumsi yang harus dipenuhi yaitu identik, independen, dan berdistribusi normal.

\section{a. Asumsi Identik}

Uji asumsi identik digunakan untuk mengetahui homogenitas variansi residual. Jika asumsi ini tidak terpenuhi artinya terdapat heteroskedastisitas yang mengaki-batkan kerugian bagi efisiensi estimator. Salah satu cara untuk mendeteksi adanya heteroskedastisitas adalah meng-gunakan uji glejser [7].

Hipotesis :

$\mathrm{H}_{0}: \sigma_{1}^{2}=\sigma_{2}^{2}=\cdots=\sigma_{n}^{2}=\sigma^{2}$

$\mathrm{H}_{1}$ : minimal ada satu $\sigma_{i}^{2} \neq \sigma^{2} ; i=1,2, \ldots, n$

Statistik uji :

$$
F_{\text {hitumg }}=\frac{\left[\sum_{i=1}^{n}\left(\left|\hat{\varepsilon}_{i}\right|-|\bar{\varepsilon}|\right)^{2}\right] /(v-1)}{\left[\sum_{i=1}^{n}\left(\left|\varepsilon_{i}\right|-\left|\hat{\varepsilon}_{i}\right|\right)^{2}\right] /(n-v)}
$$

Daerah penolakan yang digunakan adalah tolak $\mathrm{H}_{0}$ apabila $F_{\text {hitung }}>F_{\alpha ;(m+r), n-(m+r)-1)}$ atau $p$-value $<\alpha$, dimana nilai $v$ menunjukkan banyaknya parameter model glejser. Jika $\mathrm{H}_{0}$ ditolak, maka dapat disimpulkan bahwa terjadi kasus heteroskedastisitas, sehingga asumsi residual identik tidak terpenuhi.

b. Asumsi Independen

Asumsi independen adalah asumsi bahwa tidak adanya korelasi antar residual atau autokorelasi. Salah satu cara untuk mendeteksi autokorelasi adalah dengan melakukan uji Durbin Watson dengan hipotesis sebagai berikut [8].

$\mathrm{H}_{0}: \rho=0$ (residual independen)

$\mathrm{H}_{1}: \rho \neq 0$ (residual dependen)

Statistik uji : 


$$
d_{\text {hitumg }}=\frac{\sum_{t=2}^{n}\left(\varepsilon_{t}-\varepsilon_{t-1}\right)^{2}}{\sum_{t=1}^{n} \varepsilon_{t}^{2}}
$$

Daerah keputusan terbagi menjadi beberapa bagian yaitu :

1. Apabila $0<d_{\text {hitung }}<d_{L}$ atau $\left(4-d_{L}\right)<d_{\text {hitung }}<4$, maka tolak $\mathrm{H}_{0}$.

2. Apabila $d_{U}<d_{\text {hitung }}<\left(4-d_{U}\right)$, maka gagal tolak $\mathrm{H}_{0}$.

3. Apabila $d_{L} \leq d_{\text {hitung }} \leq d_{U}$ atau $\left(4-d_{U}\right) \leq d_{\text {hitung }}<\left(4-d_{L}\right)$, maka tidak ada keputusan tolak $\mathrm{H}_{0}$ ataupun gagal tolak $\mathrm{H}_{0}$.

c. Asumsi Normalitas Kolmogorov Smirnov

Uji normalitas residual dilakukan untuk mengetahui residual mengikuti distribusi normal atau tidak. Pengujian normalitas dapat dilakukan dengan uji Kolmogorov-Smirnov. Hipotesis :

$\mathrm{H}_{0}: F_{n}(x)=F_{0}(x)$ (residual berdistribusi normal)

$\mathrm{H}_{1}: F_{n}(x) \neq F_{0}(x)$ (residual tidak berdistribusi normal)

Statistik uji :

$$
D=\operatorname{maksimal}\left|F_{n}(x)-F_{0}(x)\right|
$$

Diambil keputusan tolak $\mathrm{H}_{0}$ jika $D>D_{(1-\alpha)}$ dengan nilai $D_{(1-\alpha)}$ adalah nilai kritis untuk uji Kolmogorov Smirnov satu sampel [8].

\section{F. Tingkat Partisipasi Angkatan Kerja}

Definisi dari Tingkat Partisipasi Angkatan Kerja (TPAK) menurut Badan Pusat Statistik adalah proporsi penduduk yang termasuk angkatan kerja, yakni penduduk usia kerja yang bekerja atau mempunyai pekerjaan namun sementara tidak bekerja, misalnya sedang cuti maupun yang sedang aktif mencari pekerjaan. Kelompok bukan angkatan kerja terdiri dari golongan yang bersekolah, golongan yang mengurus rumah tangga, atau melaksanakan kegiatan lainnya selain kegiatan pribadi [9].

\section{METODOLOGI PENELITIAN}

\section{A. Sumber Data}

Data yang digunakan dalam penelitian ini adalah data sekunder yang diambil dari publikasi Badan Pusat Statistik (BPS) Jawa Barat tahun 2018. Data tersebut mengenai Tingkat Partisipasi Angkatan Kerja perempuan dengan unit observasi sebanyak 27 kabupaten/kota di Jawa Barat.

\section{B. Variabel Penelitian}

Variabel yang digunakan terdiri dari variabel respon yaitu TPAK perempuan dan lima variabel prediktor yang diduga mempengaruhi TPAK perempuan di Jawa Barat. Variabel penelitian yang digunakan disajikan pada Tabel 1 .

Tabel 1. Variabel Penelitian

\begin{tabular}{cll}
\hline Variabel & \multicolumn{1}{c}{ Keterangan } & Skala \\
\hline $\mathrm{Y}$ & $\begin{array}{l}\text { TPAK perempuan } \\
\text { Persentase perempuan dengan } \\
\text { pendidikan tertinggi yang ditamatkan } \\
X_{1}\end{array}$ & Rasio \\
& Rasio \\
$X_{2}$ & $\begin{array}{l}\text { Persentase perempuan usia produktif } \\
X_{3}\end{array}$ & Rasio \\
$X_{4}$ & Persentase perempuan berstatus menikah & Rasio \\
$X_{5}$ & Produk Domestik Regional Bruto & Rasio \\
& & Rasio \\
\hline
\end{tabular}

\section{Langkah Analisis}

Berikut adalah langkah analisis yang digunakan dalam penelitian ini sesuai dengan tujuan penelitian.

1. Mendeskripsikan TPAK perempuan di Jawa Barat tahun 2018 beserta faktor-faktor yang diduga mempengaruhi.

2. Mengidentifikasi pola hubungan antara variabel respon dengan masing-masing variabel prediktor dengan menggunakan scatterplot.

3. Memodelkan variabel respon menggunakan model regresi nonparametrik spline truncated dengan satu, dua, tiga dan kombinasi knot.

4. Menentukan titik knot optimal berdasarkan nilai GCV yang paling minimum.

5. Mendapatkan model regresi nonparametrik spline truncated dengan titik knot optimal.

6. Melakukan pengujian signifikansi pada parameter regresi nonparametrik spline truncated secara serentak dan parsial.

7. Melakukan uji asumsi residual identik, independen, dan berdistribusi normal (IIDN) dari model regresi nonparametrik spline truncated.

8. Menghitung nilai koefisien determinasi $R^{2}$ dan MSE.

9. Menginterpretasi model dan menarik kesimpulan.

\section{ANALISIS \& PEMBAHASAN}

\section{A. Analisis Pola Hubungan Faktor-Faktor yang Diduga Memengaruhi TPAK Perempuan di Jawa Barat}

Mengidentifikasi pola hubungan antara variabel respon $(Y)$ dengan setiap variabel prediktor yang diduga berpengaruh menggunakan scatterplot. Berdasarkan pola hubungan yang ditunjukkan oleh scatterplot dapat ditentukan komponen parametrik dan nonparametrik. Sehingga jika telah diketahui komponen-komponen parametrik dan nonparametrik, dapat ditentukan metode yang tepat untuk melakukan pemodelan. Berikut adalah scatterplot antara persentase TPAK perempuan dengan masing-masing variabel prediktor yang ditampilkan pada Gambar 2.

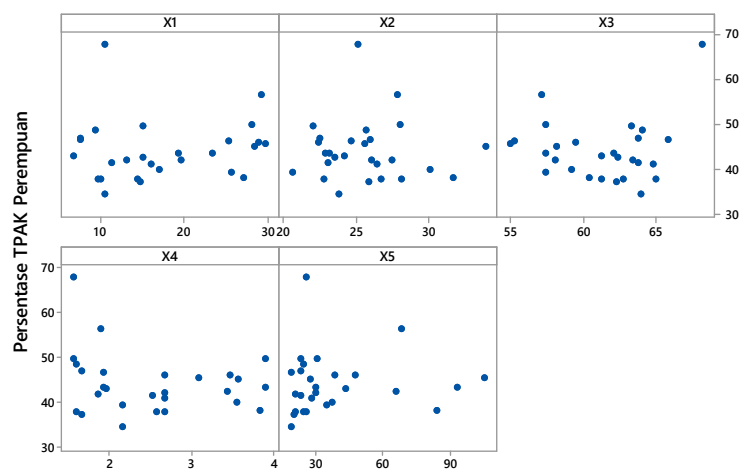

Gambar 2. Scatterplot Persentase TPAK Perempuan di Jawa Barat Tahun 2018 dengan Faktor-Faktor yang Diduga Mempengaruhinya

Berdasarkan Gambar 2, terlihat bahwa hubungan antara TPAK perempuan dengan lima faktor yang diduga mempengaruhinya tidak membentuk pola tertentu. Sehingga, variabel prediktor yang digunakan merupakan komponen nonparametrik dan cocok untuk dimodelkan dengan regresi nonparametrik spline truncated. 


\section{B. Pemilihan Titik Knot Knot}

Dari hasil yang diperoleh dari pemilihan titik knot optimum pada satu, dua, tiga, serta kombinasi knot, selanjutnya dilakukan perbandingan untuk dijadikan sebagai dasar pemilihan model terbaik. Berikut nilai GCV minimum menggunakan satu, dua, tiga dan kombinasi knot.

Tabel 2. Perbandingan Nilai GCV

\begin{tabular}{|c|c|c|}
\hline No & Knot & GCV Minimum \\
\hline 1 & Satu titik knot & 27,221 \\
\hline 2 & Dua titik knot & 12,629 \\
\hline 3 & Tiga titik knot & 6,485 \\
\hline 4 & Kombinasi knot $(3,1,3,3,3)$ & 5,013 \\
\hline
\end{tabular}

Nilai GCV yang paling minimum pada tiap titik knot, menunjukkan bahwa pemodelan regresi nonparametrik spline truncated menggunakan kombinasi titik knot pada titik $(3,1,3,3,3)$ menghasilkan nilai yang paling optimal, karena memiliki nilai GCV yang paling minimum.

\section{Pengujian Signifikansi Parameter}

Pengujian signifikansi parameter model dilakukan untuk mengetahui apakah variabel prediktor yang diduga berpengaruh signifikan terhadap TPAK perempuan di Jawa Barat atau tidak. Pengujian dilakukan secara serentak dan parsial. Pengujian serentak dilakukan dengan menggunakan statistik uji $F$ dengan hipotesis sebagai berikut.

$\mathrm{H}_{0}: \beta_{1}=\beta_{2}=\cdots=\beta_{m+r}=0$

$\mathrm{H}_{1}$ : Minimal ada satu $\beta_{j} \neq 0, j=1,2, \ldots, m+r$

Pengujian ini kemudian dibandingkan dengan nilai $F_{\text {tabel }}$ menggunakan taraf kepercayaan $95 \%$ diperoleh $F_{(0,05 ; 18 ; 8)}=$ 3,178 . Berikut hasil pengujian parameter secara serentak ditampilan pada Tabel 3.

Tabel 3. Analysis of Variance

\begin{tabular}{lccccc}
\multicolumn{5}{c}{ Tabel 3. Analysis of Variance } \\
\hline $\begin{array}{l}\text { Sumber } \\
\text { Variasi }\end{array}$ & $\boldsymbol{d} \boldsymbol{f}$ & $\boldsymbol{S S}$ & $\boldsymbol{M S}$ & $\boldsymbol{F}_{\text {hitung }}$ & $\boldsymbol{P}$-Value \\
\hline Regresi & 18 & 1177,823 & 65,435 & 35,524 & $1,065893 \mathrm{e}-05$ \\
Error & 8 & 14,736 & 1,842 & & \\
\hline Total & 26 & 1192,559 & & & \\
\hline
\end{tabular}

Berdasarkan Tabel 3 diketahui bahwa $F_{\text {hitung }}$ yang dihasilkan adalah sebesar 35,524. Dikarenakan nilai $F_{\text {hitung }}$ lebih besar dari nilai $F_{(0.05 ; 18 ; 8)}$ serta nilai $p$-value $<5 \%$, maka dihasilkan keputusan tolak $\mathrm{H}_{0}$. Hal ini menunjukkan bahwa secara serentak terdapat minimal satu variabel prediktor berpengaruh signifikan terhadap TPAK perempuan di Jawa Barat. Berdasarkan hal tersebut, maka dapat dilanjutkan untuk dilakukan uji parameter secara parsial untuk mengetahui pengaruh masing-masing variable prediktor terhadap model dengan hasil yang disajikan dalam Tabel 4.

Tabel 4. Hasil Pengujian Signifikansi Parameter Secara Parsial

\begin{tabular}{ccccc}
\hline Variabel & Parameter & Estimator & $\boldsymbol{P}$-value & Keputusan \\
\hline Konstan & $\beta_{0}$ & 21,076 & 0,007936 & Tolak $\mathrm{H}_{0}$ \\
\hline \multirow{3}{*}{$X 1$} & $\beta_{1}$ & $-34,587$ & 0,002222 & Tolak $\mathrm{H}_{0}$ \\
& $\beta_{2}$ & 33,744 & 0,002707 & Tolak $\mathrm{H}_{0}$ \\
& $\beta_{3}$ & 13,389 & 0,004690 & Tolak $\mathrm{H}_{0}$ \\
& $\beta_{4}$ & $-11,972$ & 0,008048 & Tolak $\mathrm{H}_{0}$ \\
\hline \multirow{2}{*}{$X 2$} & $\boldsymbol{\beta}_{\mathbf{5}}$ & $\mathbf{- 0 , 0 3 6}$ & $\mathbf{0 , 9 0 8 9 4 8}$ & Gagal Tolak $\mathrm{H}_{0}$ \\
& $\boldsymbol{\beta}_{\mathbf{6}}$ & $\mathbf{- 1 , 0 9 4}$ & $\mathbf{0 , 0 5 9 1 2 3}$ & Gagal Tolak $\mathrm{H}_{0}$ \\
\hline \multirow{4}{*}{$X 3$} & $\beta_{7}$ & 11,028 & 0,000121 & Tolak $\mathrm{H}_{0}$ \\
& $\beta_{8}$ & $-10,253$ & 0,000229 & Tolak $\mathrm{H}_{0}$ \\
& $\beta_{9}$ & $-54,008$ & $7,425 \mathrm{e}-05$ & Tolak $\mathrm{H}_{0}$ \\
& $\beta_{10}$ & 56,153 & $4,942 \mathrm{e}-05$ & Tolak $\mathrm{H}_{0}$ \\
\hline
\end{tabular}

Tabel 4. Hasil Pengujian Signifikansi Parameter Secara Parsial (Lanjutan)

\begin{tabular}{ccccc}
\hline Variabel & Parameter & Estimator & $\boldsymbol{P}$-value & Keputusan \\
\hline \multirow{4}{*}{$X 4$} & $\beta_{11}$ & $-211,992$ & 0,001505 & Tolak $\mathrm{H}_{0}$ \\
& $\beta_{12}$ & 190,581 & 0,003840 & Tolak $\mathrm{H}_{0}$ \\
& $\beta_{13}$ & 316,132 & 0,003840 & Tolak $\mathrm{H}_{0}$ \\
& $\beta_{14}$ & $-292,518$ & 0,005012 & Tolak $\mathrm{H}_{0}$ \\
\hline \multirow{4}{*}{$X 5$} & $\boldsymbol{\beta}_{15}$ & $\mathbf{0 , 5 5 9}$ & $\mathbf{0 , 6 8 4 9 8 9}$ & Gagal Tolak $\mathrm{H}_{0}$ \\
& $\boldsymbol{\beta}_{\mathbf{1 6}}$ & $\mathbf{- 0 , 9 0 0}$ & $\mathbf{0 , 5 1 2 3 2 4}$ & Gagal Tolak $\mathrm{H}_{0}$ \\
& $\beta_{17}$ & 12,424 & 0,000313 & Tolak $\mathrm{H}_{0}$ \\
& $\beta_{18}$ & $-12,379$ & 0,000261 & Tolak $\mathrm{H}_{0}$ \\
\hline
\end{tabular}

Informasi yang dapat diketahui dari Tabel 4 adalah terdapat empat parameter yang tidak signifikan terhadap TPAK perempuan di Jawa Barat tahun 2018 karena memiliki nilai $p$-value $>5 \%$. Sedangkan empat belas parameter lainnya berpengaruh signifikan terhadap model. Variabel prediktor dapat dikatakan berpengaruh terhadap respon apabila terdapat minimal satu parameter yang signifikan. Oleh karena itu, variabel $X_{2}$ tidak berpengaruh terhadap TPAK perempuan di Jawa Barat karena semua parameternya tidak signifikan, sedangkan variabel lainnya $X_{1}, X_{3}, X_{4}$, dan $X_{5}$ berpengaruh. Berdasarkan hal tersebut, maka dilakukan pemodelan kembali dengan menggunakan empat variabel yang berpengaruh signifikan terhadap TPAK perempuan di Jawa Barat.

\section{Pemilihan Titik Knot Optimum dengan Empat Variabel}

Berdasarkan nilai GCV minimum yang diperoleh dari satu, dua, tiga serta kombinasi titik knot, dengan langkahlangkah yang sama saat pemilihan titik knot untuk lima variabel dan selanjutnya dilakukan perbandingan guna menentukan titik knot optimum. Berikut merupakan perbandingan nilai GCV yang ditunjukkan pada Tabel 5

Tabel 5. Perbandingan Nilai GCV dengan Empat Variabel Prediktor

\begin{tabular}{ccc}
\hline No & Knot & GCV Minimum \\
\hline 1 & Satu titik knot & 21,510 \\
2 & Dua titik knot & 12,668 \\
3 & Tiga titik knot & 9,568 \\
4 & Kombinasi knot $(\mathbf{1 , 2 , 3 , 1 )}$ & $\mathbf{7 , 7 3 1}$ \\
\hline
\end{tabular}

Tabel 5 menunjukkan bahwa nilai GCV paling minimum dihasilkan oleh kombinasi knot $(1,2,3,1)$. Nilai GCV yang dihasilkan adalah sebesar 7,731. Oleh karena itu, dapat diketahui bahwa model regresi nonparametrik spline truncated yang terbaik adalah model spline dengan jumlah parameter sebanyak 12 termasuk parameter $\beta_{0}$. Berikut merupakan hasil estimasi parameter menggunakan metode Ordinary Least Square (OLS) dengan kombinasi knnot $(1,2,3,1)$ sebagai titik knot optimal.

$$
\begin{aligned}
& \hat{y}_{i}=232,527-0,693 x_{1}+1.073\left(x_{1}-16,197\right)_{+}+1,372 x_{3}- \\
& 10,251\left(x_{3}-58,416\right)_{+}+11,760\left(x_{3}-60,043\right)_{+}-164,540 x_{4}+ \\
& 143,743\left(x_{4}-1,607\right)_{+}+168,077\left(x_{4}-2,281\right)_{+}- \\
& \quad 146,212\left(x_{4}-2,329\right)_{+}+0,403 x_{5}-0.536\left(x_{5}-54,363\right)_{+} \\
& \text {E. Pengujian Signifikansi Parameter Model dengan Empat } \\
& \quad \text { Variabel }
\end{aligned}
$$

Pengujian dilakukan secara serentak dan parsial. Pengujian serentak dilakukan dengan menggunakan statistik uji $F$ dengan hipotesis sebagai berikut.

$\mathrm{H}_{0}: \beta_{1}=\beta_{2}=\cdots=\beta_{11}=0$

$\mathrm{H}_{1}$ : Minimal ada satu $\beta_{j} \neq 0, j=1,2, \ldots, 11$

Berikut hasil pengujian parameter secara serentak ditampilan pada Tabel 6 . 
Tabel 6. Analysis of Variance dengan Empat Variabel

\begin{tabular}{lccccc}
\hline $\begin{array}{l}\text { Sumber } \\
\text { Variasi }\end{array}$ & $\boldsymbol{d} \boldsymbol{f}$ & $\boldsymbol{S S}$ & $\boldsymbol{M S}$ & $\boldsymbol{F}_{\text {hitung }}$ & $\boldsymbol{P}$-Value \\
\hline Regresi & 11 & 1128,251 & 102,5683 & 23,88221 & $1,632 \times 10^{-7}$ \\
Error & 15 & 64,42135 & 4,294757 & & \\
\hline Total & 26 & 1192,672 & & & \\
\hline
\end{tabular}

Pada Tabel 6 diketahui bahwa nilai pengujian serentak parameter model menghasilkan nilai $p$-value $<5 \%$. Oleh karena itu, dapat diputuskan Tolak $\mathrm{H}_{0}$ yang memiliki arti bahwa terdapat minimal satu parameter model memberikan pengaruh secara signifikan terhadap TPAK perempuan di Jawa Barat tahun 2018. Berdasarkan hal tersebut, perlu dilakukan pengujian parsial untuk mengetahui variabel mana saja yang berpengaruh terhadap variabel respon.

Tabel 7. Hasil Pengujian Signifikansi Parameter Secara Parsial

\begin{tabular}{ccccc}
\hline $\begin{array}{c}\text { Variabe } \\
\mathbf{1}\end{array}$ & $\begin{array}{c}\text { Paramete } \\
\mathbf{r}\end{array}$ & $\begin{array}{c}\text { Estimato } \\
\mathbf{r}\end{array}$ & $\boldsymbol{P}$-value & $\begin{array}{c}\text { Keputusa } \\
\mathbf{n}\end{array}$ \\
\hline konstan & $\beta_{0}$ & 232,527 & 0,02243298 & Tolak $\mathrm{H}_{0}$ \\
\hline \multirow{3}{*}{$X 1$} & $\beta_{1}$ & $-0,693$ & 0,003604737 & Tolak $\mathrm{H}_{0}$ \\
& $\beta_{2}$ & 1,073 & 0,000846491 & Tolak $\mathrm{H}_{0}$ \\
& $\boldsymbol{\beta}_{3}$ & $\mathbf{1 , 3 7 2}$ & $\mathbf{0 , 1 0 2 1 2 4 8}$ & Gagal \\
& & & 0,000118648 & Tolak $\mathrm{H}_{0}$ \\
$X 3$ & $\beta_{4}$ & $-10,251$ & 6 & \\
& & & & \\
& $\beta_{5}$ & 11,760 & $2,20809 \mathrm{e}-06$ & Tolak $\mathrm{H}_{0}$ \\
\hline \multirow{4}{*}{$X 4$} & $\beta_{6}$ & $-164,540$ & 0,004826447 & Tolak $\mathrm{H}_{0}$ \\
& $\beta_{7}$ & 143,743 & 0,013891 & Tolak $\mathrm{H}_{0}$ \\
& $\beta_{8}$ & 168,077 & 0,003120723 & Tolak $\mathrm{H}_{0}$ \\
& $\beta_{9}$ & $-146,212$ & 0,006134994 & Tolak $\mathrm{H}_{0}$ \\
\hline \multirow{2}{*}{$X 5$} & $\beta_{10}$ & 0,403 & $7,30369 \mathrm{e}-06$ & Tolak $\mathrm{H}_{0}$ \\
& $\beta_{11}$ & $-0,536$ & $6,13905 \mathrm{e}-05$ & Tolak $\mathrm{H}_{0}$ \\
\hline
\end{tabular}

Tabel 7 menunjukkan terdapat satu parameter yang tidak signifikan dalam model karena memiliki nilai $p$-value $>5 \%$. Namun, jika dilihat dari masing-masing variabel $X_{1}, X_{3}, X_{4}$, serta $X_{5}$ dapat diketahui bahwa minimal terdapat satu parameter yang signifikan dalam model. Oleh karena itu, dapat disimpulkan bahwa keempat variabel prediktor yang digunakan yaitu persentase perempuan dengan pendidikan tertinggi yang ditamatkan minimal SLTA $\left(X_{1}\right)$, persentase perempuan berstatus menikah $\left(X_{3}\right)$, UMK $\left(X_{4}\right)$, dan PDRB per kapita $\left(X_{5}\right)$ memengaruhi persentase TPAK perempuan di Jawa Barat.

\section{F. Pengujian Asumsi Residual}

Berikut merupakan pengujian asumsi yang dilakukan pada model kedua dengan menggunakan empat variabel prediktor.

1. Asumsi Identik

Pengujian asumsi residual identik dilakukan untuk mengetahui apakah varians residual telah homogen atau tidak terjadi heterokedastisitas. Berikut merupakan hasil pengujian asumsi identik dengan menggunakan uji Glejser.

\begin{tabular}{cccccc}
\multicolumn{6}{c}{ Tabel 8. Hasil Pengujian Statistik Uji Glejser } \\
\hline Sumber & df & SS & MS & F hit & P-value \\
\hline Regresi & 11 & 7,38714 & 0,6716 & 0,51167 & 0,8670 \\
Error & 15 & 19,6873 & 1,3125 & & \\
Total & 26 & 27,0745 & & &
\end{tabular}

Berdasarkan Tabel 8 diperoleh nilai $p$-value $=0,8670$. Karena nilai $p$-value $>5 \%$, maka menghasilkan keputusan Gagal Tolak $\mathrm{H}_{0}$. Hal ini menunjukkan tidak terjadi heterokedastisitas pada model, sehingga asumsi residual identik terpenuhi.

2. Asumsi Independen

Pengujian asumsi residual independen digunakan untuk mendeteksi terjadinya autokorelasi antar residual dari model, Pengujian asumsi independen dilakukan dengan menggunakan Durbin Watson dengan hasil pada Tabel 18.

Tabel 9. Hasil Pengujian Statistik Uji Durbin Watson

\begin{tabular}{ccccc}
\hline$d_{\text {hitung }}$ & $d_{L ; 0.05}$ & $d_{U ; 0.05}$ & $4-d_{L ; 0.05}$ & $4-d_{U ; 0.05}$ \\
\hline 1,915438 & 1,1624 & 1,651 & 2,8376 & 2,349 \\
\hline
\end{tabular}

Tabel 9 menunjukkan bahwa nilai dhitung yang dihasilkan pada uji Durbin-Watson sebesar 1,915438. Apabila $d_{\text {hitung }}$ dibandingkan dengan $d_{\mathrm{U}, 0.05}$ dan $4-d_{\mathrm{U} ; 0.05}$, dapat diketahui bahwa $d_{\mathrm{U} ; 0.05}<d_{\text {hitung }}<4-d_{\mathrm{U} ; 0.05}$, maka menghasil-kan keputusan Gagal Tolak $\mathrm{H}_{0}$. Hal ini menunjuk-kan tidak terjadi autokorelasi pada model, sehingga asumsi residual independen terpenuhi terpenuhi.

3. Asumsi Distribusi Normal

Pengujian normalitas data dapat dilakukan dengan menggunakan statistik uji Kolmogorov-Smirnov. Berikut merupakan hasil pengujian asumsi distribusi normal dengan uji Kolmogorov-Smirnov.

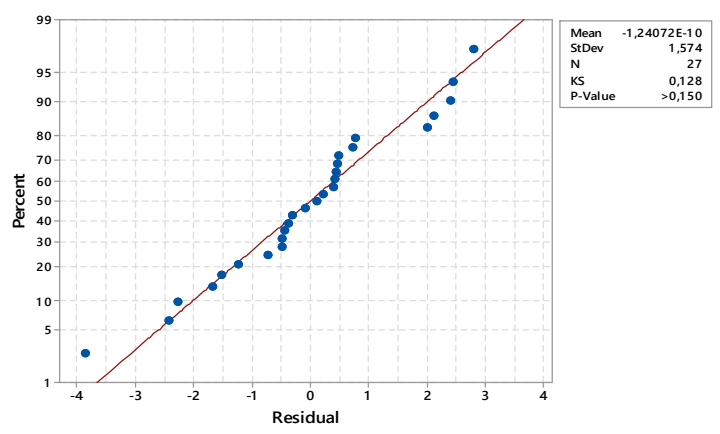

Gambar 3. Plot Normalitas Residual

Titik plot residual yang ditunjukkan pada Gambar 3 menunjukkan penyebaran titik plot residual berada pada sumbu diagonal dari grafik, sehingga hal ini mengindikasi-kan residual berdistribusi normal. Keputusan yang diperoleh adalah Gagal Tolak $\mathrm{H}_{0}$ karena nilai $p$-value $>5 \%$. Oleh karena itu, dapat ditarik kesimpulan bahwa residual mengikuti pola distribusi normal, maka model telah memenuhi asumsi residual distribusi normal.

\section{G. Interpretasi Model Terbaik}

Model terbaik regresi nonparametrik spline truncated pada TPAK perempuan di Jawa Barat tahun 2018 merupakan model yang terdiri dari empat variabel prediktor dengan menggunakan titik kombinasi 1,2,3,1. Berikut merupakan interpretasi dari regresi nonparametrik spline truncated pada TPAK perempuan di Jawa Barat tahun 2018.

1. Ketika variabel $X_{3}, X_{4}$, dan $X_{5}$ dianggap konstan, maka pengaruh pendidikan tertinggi yang ditamatkan minimal SLTA $\left(X_{1}\right)$ terhadap TPAK perempuan di Jawa Barat adalah sebagai berikut :

$$
\begin{aligned}
\hat{y} & =232,527-0,693 x_{1}+1,073\left(x_{1}-16,197\right)_{+} \\
& = \begin{cases}232,527-0,693 x_{1} & ; x_{1}<16,197 \\
215,148+0,38 x_{1} & ; x_{1} \geq 16,197\end{cases}
\end{aligned}
$$


Berdasarkan model dapat dijelaskan bahwa ketika persentase perempuan dengan pendidikan tertinggi yang ditamatkan minimal SLTA suatu kabupaten/kota di Jawa Barat lebih dari 16,197, maka setiap kenaikan sebesar 1 persen mengakibatkan TPAK perempuan naik sebesar 0,4 persen. Sedangkan apabila kabupaten/kota di Jawa Barat memiliki persentase perempuan dengan pendidikan tertinggi yang ditamatkan minimal SLTA kurang dari 16,197 persen maka setiap kenaikan $X_{1}$ sebesar 1 persen akan menurunkan TPAK perempuan di Jawa Barat sebanyak 0,7 persen.

2. Ketika variabel $X_{1}, X_{4}$, dan $X_{5}$ dianggap konstan, maka pengaruh perempuan berstatus menikah $\left(X_{3}\right)$ terhadap TPAK perempuan di Jawa Barat adalah sebagai berikut : $\hat{y}=232,527+1,372 x_{3}-10,251\left(x_{3}-58,416\right)_{+}+11,760\left(x_{3}-60,043\right)_{+}$

$$
= \begin{cases}232,527+1,372 x_{3} & ; x_{3}<58,416 \\ 831,350-8,879 x_{3} & ; 58,416 \leq x_{3}<60,043 \\ -473,579+13,132 x_{3} & ; x_{3} \geq 60,043\end{cases}
$$

Berdasarkan model tersebut dapat dijelaskan bahwa jika suatu daerah memiliki persentase perempuan berstatus menikah lebih besar dari 60,043 persen dan naik sebesar 1 persen maka persentase TPAK perempuan akan cenderung naik sebesar 13,1 persen. Sedangkan jika kabupaten/kota di Jawa Barat memiliki persentase perempuan berstatus menikah bernilai di antara 58.416 hingga 60,043 dan naik sebesar 1 persen, maka persentase TPAK perempuan cenderung turun sebesar 8,879 persen.

3. Ketika variabel $X_{1}, X_{3}$, dan $X_{5}$ dianggap konstan, maka pengaruh UMK $\left(X_{4}\right)$ terhadap TPAK perempuan di Jawa Barat adalah sebagai berikut :

$$
\begin{aligned}
\hat{y} & =232,527-164,540 x_{4}+143,743\left(x_{4}-1,607\right)_{+}+ \\
& 168,077\left(x_{4}-2,281\right)_{+}-146,212\left(x_{4}-2,329\right)_{+} \\
& = \begin{cases}232,527-164,540 x_{4} & ; x_{4}<1,607 \\
1,532-20,797 x_{4} & ; 1,607 \leq x_{4}<2,281 \\
-150,857+3,537 x_{4} & ; 2,281 \leq x_{4}<2,329 \\
573,055-310,752 x_{4} & ; x_{4} \geq 2,329\end{cases}
\end{aligned}
$$

Berdasarkan model tersebut dapat dijelaskan bahwa ketika nilai UMK berada di antara 2,281 juta hingga 2,329 juta dan naik 0,01 juta, maka persentase TPAK perempuan akan cenderung naik sebesar 0,03 persen. Ketika nilai UMK lebih dari 2,329 juta menunjukkan setiap kenaikan UMK sebesar 0,01 juta akan mengakibat-kan persentase TPAK perempuan turun sebesar 3,1 persen. Selanjutnya jika UMK kurang dari 1,607 juta maka setiap kenaikan UMK sebesar 0,01 juta akan mengakibatkan persentase TPAK perempuan turun sebanyak 1,645 persen.

4. Ketika variabel $X_{1}, X_{3}$, dan $X_{4}$ dianggap konstan, maka pengaruh PDRB $\left(X_{5}\right)$ terhadap TPAK perempuan di Jawa Barat adalah sebagai berikut :

$$
\begin{aligned}
\hat{y} & =232,527+0,403 x_{5}-0,536\left(x_{5}-54,363\right)_{+} \\
& = \begin{cases}232,527+0,403 x_{5} & ; x_{5}<54,363 \\
261,666-0,134 x_{5} & ; x_{5} \geq 54,363\end{cases}
\end{aligned}
$$

Berdasarkan model tersebut dapat dijelaskan bahwa ketika suatu kabupaten/kota di Jawa Barat dengan PDRB bernilai kurang dari 54,363 juta dan meningkat sebesar 1 juta rupiah dengan asumsi variabel prediktor lain tetap, maka persentase TPAK perempuan akan naik sebesar 0,403 persen. Ketika PDRB suatu daerah lebih dari 54,363 juta meningkat sebesar 1 juta rupiah, maka persentase TPAK perempuan turun 0,134 persen.

\section{KESIMPULAN \& SARAN}

\section{A. Kesimpulan}

Berdasarkan analisis pemodelan dengan menggunakan metode regresi nonparametrik spline truncated, model terbaik dihasilkan dengan hanya menggunakan empat variable prediktor. Variabel yang tidak berpengaruh terhadap TPAK perempuan di Jawa Barat tahun 2018 adalah variabel persentase perempuan usia produktif $\left(X_{2}\right)$, sementara untuk variabel persentase perempuan dengan pendidikan tertinggi yang ditamatkan minimal SLTA $\left(X_{1}\right)$, persentase perempuan berstatus menikah $\left(X_{3}\right)$, UMK $\left(X_{4}\right)$, produk domestik regional bruto $\left(X_{5}\right)$. Dengan menggunakan empat variabel, model terbaik dihasilkan saat menggunakan kombinasi knot 1,2,3,1. Berikut merupakan model regresi yang didapatkan.

$$
\begin{aligned}
\hat{y}_{i}= & 232,527-0,693 x_{i 1}+1,073\left(x_{i 1}-16,197\right)_{+}+1,372 x_{i 3}- \\
& 10,251\left(x_{i 3}-58,416\right)_{+}+11,760\left(x_{i 3}-60,043\right)_{+}-164,540 x_{i 4}+ \\
& 143,743\left(x_{i 4}-1.607\right)_{+}+168,077\left(x_{i 4}-2,281\right)_{+}- \\
& 146,212\left(x_{i 4}-2.329\right)_{+}+0,403 x_{i 5}-0,536\left(x_{i 5}-54,363\right)_{+}
\end{aligned}
$$

Model yang diperoleh telah memenuhi ketiga asumsi residual dengan koefisien determinasi yang dihasilkan oleh model terbaik adalah sebesar 94,59 persen yang memiliki arti bahwa variabel prediktor $X_{1}, X_{3}, X_{4}$, dan $X_{5}$ mampu menjelaskan variabilitas persentase TPAK perempuan di Jawa Barat tahun 2018 sebesar 94,59 persen, sedangkan sisanya dijelaskan oleh variabel prediktor lain yang tidak termasuk ke dalam model.

\section{B. Saran}

Berdasarkan hasil penelitian mengenai faktor-faktor yang mempengaruhi TPAK perempuan di Jawa Barat, disarankan kepada pemerintah daerah agar lebih fokus pada daerahdaerah yang memiliki persentase TPAK perempuan yang masih rendah dengan memperhatikan aspek upah minimum kabupaten/kota serta pendidikan masyarakat. Selain itu, pemerintah dapat memberdayakan perempuan melalui pelatihan khusus, misalnya pelatihan kerajinan payet, membatik, dan sebagainya. Pelatihan tersebut sangat diperlukan terutama bagi perempuan yang sudah berumah tangga agar tetap memiliki aktivitas lain yang dapat membantu perekonomian keluarga.

\section{DAFTAR PUSTAKA}

[1] International-Labour-Organization, Key Indicators of the Labour Market, Ninth Edition, Geneva: International Labour Office., 2016.

[2] Badan-Pusat-Statistik-Jawa-Barat, Keadaan Angkatan Kerja Provinsi Jawa Barat Agustus 2018, Jawa Barat: BPS Provinsi Jawa Barat, 2018. 
[3] R. L. Eubank, Nonparametric Regression and Spline Smoothing (2nd Edition.), USA: Marcel Dekker, 1999.

[4] W. Hardle, Applied Nonparametric Regression, New York: Cambridge University Press, 1990.

[5] I. N. Budiantara, "Model Spline dengan Knot Optimal," Jurnal Ilmu Dasar, vol. 7, pp. 77-85, 2006.

[6] N. R. Draper and H. Smith, Applied Regression Analysis (3rd Edition), New York: John Wiley and Sons Inc, 1998.

[7] D. Gujarati, Basic Econometrics (4th edition), New York: The McGraw-Hill., 2004.

[8] W. W. Daniel, Statistika Non Parametrik., Jakarta: PT. Gramedia, 1989.

[9] R. D. Handoyo, Ekonomi Sumber Daya Manusia., Surabaya: Universitas Airlangga., 2008. 